\title{
Engaging in Scholarly Teaching to Transform Practice: Encouragement for Reluctant Colleagues
}

\author{
Gregg Wentzell, PhD \\ Assistant Director of the Center for Teaching Excellence \\ Miami University
}

If you are reading this issue of InSight: A Journal of Scholarly Teaching, you probably have an interest in and appreciation for evidence-based teaching and learning. Perhaps you already are passionate about the value of classroom research, and you regularly set learning outcomes, consult methods based in the literature to design instruction that will help students achieve those outcomes, assess, and reflect on the results to adjust instruction in ways that will improve student learning. You may even be a seasoned practitioner of the scholarship of teaching and learning (SoTL). Some of you may have presented results of your work at one or more teaching and learning conferences, or even published it in one of the peer-reviewed SoTL venues.

You likely know colleagues, however, who have not yet acquired your passion. They may truly care about their students and their learning, but they are convinced that the tyranny of content still must rule the day and that there is no time to try out and assess innovative classroom techniques. Or maybe disciplinary scholarship, still the coin of the realm in academe, occupies most of their time and energy. Whatever their reasoning, as an advocate of a scholarly approach to teaching, you, have the ability to help your colleagues transform their practice and, in turn, their students' learning. If you often feel you are the only one in your department (or on your campus) who is passionate about student-centered, evidence-based teaching, don't despair; what follows is advice for persuading your reluctant peers to join the conversation.

First things first, what is scholarly teaching? As Richlin (2001) defines it, scholarly teaching is intended "to impact the activity of teaching and the resulting learning" (p. 58). Scholarly teachers engage in several activities with the goal of improved student learning. They (a) investigate (in the literature) what has been attempted to solve similar pedagogical problems or challenges, (b) select the teaching method that offers the best opportunity for helping students achieve the desired learning objective, and (c) observe and record the application of this method in a systematic way. Your peers may be heartened to realize they are already doing some of these activities.

Why are faculty interested in taking a scholarly approach to teaching? Some who are new to the conversation may question its benefits to them and to students - or they simply may need reassurance that the efforts are worth it. First of all, scholarly teaching allows us to explore questions about teaching and learning that interest us. It also offers insight into our own instructional biases (e.g., questioning our assumptions about student performance): "Why do some of my students consistently underperform?" "Why do I always have difficulty when I teach X topic?" Moreover, empirical evidence is necessary to know whether students are actually learning (just as we need evidence for our disciplinary research). Investigating new teaching 
approaches also helps keep our teaching fresh and viable over time, and it allows us to learn in new ways from both our students and our peers (Bishop-Clark \& Dietz-Uhler, 2012). Finally, engaging in scholarly approaches to teaching can help us get greater recognition for an important part of the work we do, as Ernest Boyer (1990) advocated.

\section{The Scholarly Process}

Once faculty have begun to open their minds to the benefits of a scholarly approach to teaching, it is useful to offer them a framework for doing the work. The Ongoing Cycle of Scholarly Teaching and the Scholarship of Teaching (SoTL) (adapted from Richlin, 2001) is effective for illustrating the scholarly process: (1) describe the problem, question, or opportunity; (2) provide the context; (3) propose a solution; (4) establish a baseline; (5) assess the results; and (6) communicate the results (and repeat these steps as necessary).

\section{Step 1: Describe the Problem, Question, or Opportunity}

Scholarly teaching begins with a need to impact student learning. Encourage your colleagues to describe what they see in their students' behavior or their institution's approach that they wish to change and why. Suggest they tie this question

Scholarly teaching begins with a need to impact student learning. to course learning objectives - "What do you want students to be able to do?" - and phrase it in measurable terms, such as "After I complete this project, my students will be better able to [define, analyze, identify, etc.]." Remind your peers that many variables can affect a project's outcome, including who they are, who their students are, the content they are teaching, and even environmental factors such as the classroom itself.

Some teaching and learning problems that could be well-suited to scholarly teaching projects include a need to impact student behavior (e.g., improving classroom discussion, helping students overcome math or science anxiety); a desire to better achieve a course learning objective through an innovative method (e.g., the flipped classroom, team-based learning); or a challenge to improve learning or other concerns regarding an institutional approach (Cox \& Wentzell, 2016).

\section{Step 2: Provide the Context}

Just as in the disciplines, when doing research in teaching, it is important to consult the literature. Doing so allows us to build on what is already known and avoid duplicating ineffective practices. Prospective scholarly teachers should ask themselves, "What have others done (at my institution and elsewhere) to address this question? What is different about my approach?" Resources for the literature search include search engines such as Google Scholar as well as selected bibliographies of SoTL resources, including disciplinary and multidisciplinary pedagogy journals (see, for example, http://cetl.kennesaw.edu/teaching-journals-directory) and teaching conferences. The Original Lilly Conference on College Teaching (www.miamioh.edu/lillycon/) provides a list of all Conference session keywords. 
When 10 or more sessions include the same keyword, it is listed as a Theme Track. The annual listing of theme tracks provides an effective way to determine which teaching and learning research topics and approaches are popular (and which may be underinvestigated).

\section{Step 3: Propose a Solution}

With a context for what has been done to address the problem or question established, it is time to propose a solution. Some possible approaches to recommend to peers, depending on their learning objectives, their students, and their course, could be to introduce the use of writing, music, visuals, or reflection in class; to use personal responders (clickers) in class for a few weeks; or to put students in groups for a course unit.

\section{Step 4: Establish a Baseline}

In order to know whether a new approach has made a difference in student learning, it is important to understand where students are at the outset. What will your peers use for comparison to show change or impact? Possible measures could be outcomes from a previous time they taught the course: grades, student work, retention; first-day or early-term survey results from the class; or a "control group," someone teaching the same course but not attempting the intervention (this could be the same person if he or she is teaching more than one section).

\section{Step 5: Assess the Results}

The next step is to determine the effectiveness and impact of the solution. Many formative options are readily available to recommend to new scholarly teachers, and many of these new teachers may already be using one or more of these methods in some form: pre- and post-surveys of learner reactions and/or results, retention in the course or unit over the term, reflections in an instructor's journal, focus groups, and classroom assessment techniques, to name a few. Among these methods, classroom assessment techniques (CATs), developed by Angelo and Cross (1993), are an ideal method of collecting data for small classroom research projects because they are generally short, ungraded, anonymous, informal assessment measures that can be used as often as necessary to gauge student learning. It is also easy to tie CATs to learning objectives using a self-administered assessment of instructional goals like the Teaching Goals Inventory (https://fm.iowa.uiowa.edu/fmi/xsl/tgi/data_entry.xsl?-db=tgi_data\&lay=Layout $01 \&$-view).

\section{Step 6: Communicate the Results}

How can instructors use assessment data in their teaching? The possible applications and outcomes are vast! A scholarly teacher would begin by comparing the results to a baseline (and the literature). Upon reflection, the next step is to incorporate the findings into teaching as appropriate, and then to assess again to note changes in student learning. Encourage your colleagues to share results with students,

InSight: A Journal of Scholarly Teaching 11


including comparisons to findings from the literature, to invite their buy-in. If we can show students that our teaching is based on sound research (including our own), they understand much better why we do what we do in the classroom and are more likely to accept methods that may be unfamiliar to them. Finally, share the results with colleagues to compare results, discover new approaches and interpretations, and continue to grow as a teacher-scholar.

Those engaging in this scholarly If we can show students that our process should repeat these six steps as needed to refine and expand their practice. Some instructors may wish to take the next step, to the scholarship of teaching and learning, by submitting their work for a peer-reviewed presentation or publication. While this is another discussion that would require more teaching is based on sound research (including our own), they understand much better why we do what we do in the classroom and are more likely to accept methods that may be unfamiliar to them.

space than we have here, possible venues to explore include teaching and learning conferences such as the Lilly Conferences on College Teaching (www.lillyconferences.com), newsletters (The Teaching Professor; The National Teaching and Learning Forum), journals of specific disciplines (Teaching Sociology; Teaching of Psychology), and journals across disciplines (Journal on Excellence in College Teaching; Innovative Higher Education).

\section{Caveats and Resources for Support}

A few caveats and resources may be helpful to peers who are new to scholarly teaching. First, try out new techniques for a course lesson or unit first to see how well they work-wholesale new approaches could encounter student resistance (Cox \& Wentzell, 2016). Second, it is wise to obtain IRB (Human Subjects) approval in case the instructor may want to present or publish the results. Campus offices can provide support for data collection and interpretation if desired-in particular, the offices of institutional research, statistical consulting, the library, the teaching and learning center, and the psychology and educational psychology departments (Cox \& Wentzell, 2016).

Finally, colleagues who are new to the field may need to be disabused of scholarly teacher Impostor Syndrome. After all, it took years to become an expert in their discipline-how can they acquire expertise in another area of research without investing significant time? However, classroom research is designed for the intelligent non-expert, and it is relatively free of jargon. They may reach the frontier in their area of interest relatively quickly.

The articles in this issue of InSight all began with their authors doing scholarly teaching in some form. Spread the word among your colleagues. They could transform their own practice-by questioning their assumptions and biases and engaging in fresh, more effective approaches-and their students' learning-by investigating how they learn, what motivates them, and, ultimately, how better to help them become enlightened, global citizens (McGuire, 2015). By communicating their results in various forms, these new scholarly teachers - in large part because of your encouragement and support-may even change the culture in their department or 
across the campus more broadly. For your peers, for students, and for the campus as a whole-become a scholarly teaching advocate!

\section{References}

Angelo, T. A., \& Cross, K. P. (1993). Cox, M. D., \& Wentzell, G. W. (2016, Classroom assessment techniques: A November). Turn your Lilly Conference handbook for college teachers ( $2^{\text {nd }}$ ed.). San presentation into a SoTL publication. Francisco, CA: Jossey-Bass.

Workshop presented at the Original Lilly Conference on College Teaching,

Bishop-Clark, C., \& Dietz-Uhler, B. Oxford, OH.

(2012). Engaging in the scholarship of teaching and learning: A guide to the process, and how to develop a project from start to finish. Sterling, VA: Stylus.

McGuire, S. Y. (2015). Teach students how to learn: Strategies you can incorporate into any course to improve student metacognition, study skills, and motivation.

Boyer, E. L. (1990). Scholarship Sterling, VA: Stylus.

reconsidered: Priorities of the professoriate. Princeton, NJ: The Carnegie Foundation for the Advancement of Teaching.

Richlin, L. (2001). Scholarly teaching and the scholarship of teaching and learning. In C. Kreber (Ed.), Scholarship revisited: Perspectives on the scholarship of teaching (pp. 57-68). New Directions for Teaching \& Learning, No. 86. San Francisco, CA: Jossey-Bass.

Gregg W. Wentzell is Assistant Director of the Center for Teaching Excellence at Miami University and co-directs the Center's New Faculty Teaching Enhancement Program. He is Managing Editor of the Journal on Excellence in College Teaching and the Learning Communities Journal. In addition to being Lilly Conference on College Teaching Associate Director, Gregg does faculty consulting on teaching and writing and presents seminars on the Scholarship of Teaching and Learning both on-campus and at teaching and learning conferences. 